\title{
The analytical framework of water and armed conflict: a focus on the 2006 Summer War between Israel and Lebanon
}

\author{
Mark Zeitoun Reader, Water Security Research Centre, School of International \\ Development, University of East Anglia, United Kingdom, Karim Eid-Sabbagh \\ PhD Candidate, School of Oriental and African Studies, University of London, \\ United Kingdom, and Jeremy Loveless Independent Consultant, United Kingdom
}

This paper develops an analytical framework to investigate the relationship between water and armed conflict, and applies it to the 'Summer War' of 2006 between Israel and Lebanon (Hezbollah). The framework broadens and deepens existing classifications by assessing the impact of acts of war as indiscriminate or targeted, and evaluating them in terms of international norms and law, in particular International Humanitarian Law (IHL). In the case at hand, the relationship is characterised by extensive damage in Lebanon to drinking water infrastructure and resources. This is seen as a clear violation of the letter and the spirit of IHL, while the partial destruction of more than 50 public water towers compromises water rights and national development goals. The absence of pre-war environmental baselines makes it difficult to gange the impact on water resources, suggesting a role for those with first-hand knowledge of the hostilities to develop a more effective response before, during, and after armed conflict.

Keywords: humanitarian intervention, Israel-Lebanon 2006 Summer War, water and war, water conflict, water security, urban armed conflict, urban water

\section{Introduction}

This paper has two objectives: (i) to present an analytical framework that can serve to interpret the breadth and the depth of the relationship between water and armed conflict; and (ii) to employ this framework in an exploration of the 'Summer War' of 2006 between Israel and Lebanon (Hezbollah). The 'analytical framework of water and armed conflict' is based on the authors' experience of implementing water projects throughout the world, as well as on the water conflict chronology classification developed by Gleick (20II). This classification is first broadened by expanding water infrastructure and resources to encompass water institutions and trans-boundary water conflict, and then deepened through characterisation of the nature of the damage resulting from acts of war (discriminate or indiscriminate) according to international norms. The latter include principles of environmental justice, the Human Right to Water, International Humanitarian Law (IHL), International Water Law (IWL), the Law of Belligerent Occupation (LBO), the Millennium Development Goals (MDGs), and the developing concepts of warfare ecology, 'ecocide', and 'environmental crime'. In other words, the framework appreciates that the water-war relationship 
is mediated by the motives and the means of the combatants who wage war, and the politicians who choose war, as well as by more distantly engaged lawyers and social activists.

The Summer War of 2006 provides an interesting case with which to develop and test the framework, in part because of the long history of instability in the region. A century of armed struggle to define the borders of Lebanon, Israel, and British Mandate Palestine has not spared water infrastructure and resources (see Zeitoun et al., 20I2, Table 5.3). The archival record explored suggests a direct relation between the changing nature of warfare and the type and extent of water-related damage. The bulk of destruction in the warfare of the I940s was the product of ground operations or artillery combat, for instance, whereas the damage experienced in the I980s was due primarily to air strikes (especially during the Israeli invasion of Beirut, Lebanon, in I982). The war of 2006, fought by the Israel Defense Forces (IDF) and Lebanon's armed Hezbollah political party and militia, may be viewed as the latest episode in a process that is evolving only in terms of the quality of documentation.

The 33-day (I2 July-I4 August 2006) war had an immense impact on public mental health, the economy (Eid-Sabbagh, 2007), and regional stability (Achcar and Warschawski, 2007). Arguments have been made that it also established a new combat doctrine of 'disproportionality' - that was used to even harsher effect three years later in Gaza (Goodman, Menuchin, and Oron, 2009) — claiming the lives of more than I, ooo people and injuring more than 4,00o others (mainly civilians). The war was fought principally with aircraft, artillery, and tanks by the IDF, and with antitank weapons and artillery by Hezbollah. Most of the ground combat occurred in South Lebanon, although the Israeli Air Force also struck further north (notably in Beirut and the Beka'a Valley). As will be seen, the magnitude and the type of damage to water infrastructure, institutions, and resources on both sides of the border reflects directly the means of war.

The water-war relationship is explored using the 'analytical framework of water and armed conflict', which is developed in the following section. The paper then investigates the impact of the war on Lebanese public water reservoirs, and on the Lebanon-Israel conflict over the upper reaches of the Jordan River. The analysis reveals that the destruction of water and wastewater infrastructure is a clear violation of the letter and the spirit of IHL, that the damage to public water reservoirs also is a violation of the Human Right to Water, and that the Jordan River conflict is of negligible relevance. Two methodological challenges are identified:

- the difficulties of gauging impact in the absence of pre-war environmental baselines; and

- the need for first-hand observation and knowledge of hostilities to assess the character of the damage.

The study concludes by recommending a role for humanitarian actors before, during, and after an armed conflict. 


\section{Understanding water and war and developing the analytical framework}

In one sense 'water' may be considered as a subset of the 'war-environment relationship' that Pearson (20I2, p. II6) describes from a historical landscape perspective. The body of research on the reproducing relationship between war and water is slim, however, compared with geography and political ecology research into more 'lootable' natural resources (see, for example, Le Billon, 200I). While international water conflicts-whether violent (Gleditsch et al., 2006) or non-violent (Zeitoun and Warner, 2006) - have attracted significant attention, the work is limited to exploration of water resources as a goal of conflict. Water as a target, victim, or weapon of war has been scrutinised much less. As Peluso and Vandergeest (20I I) argue with respect to forests, water is a highly politicised (and securitised) resource (see also Julien, 20I2), and this relationship deserves considerably more attention.

The subsequent sections review relevant research from the overlapping categories of international environmental and water norms, and international environmental and water law. The term 'water' is used loosely here to denote water resources, water infrastructure, water institutions, and hydro-politics. 'War' is somewhat compromised shorthand for 'armed conflict', although the latter is retained where there is a direct bearing on international law.

\section{International water norms relevant to access, equity, and sustainability}

The most established norms relevant to water and war have their origins in the development of thinking on social justice, as set out by Rawls (I97I), Sen (2009), and many others. From this vast field of thought come at least two important principles: equitable distribution of harm and benefits; and retribution for past harm. Research on environmental justice has replicated social justice's reach into history to consider the future-and raises concerns for inter-generational justice, primarily through the notion of environmental sustainability (see, for example, Schlosberg, 2004; Hiskes, 2006). The quest for justice is expected to have considerable relevance for conflict resolution efforts that address the root causes of water conflicts.

The norms derived from social justice thinking sit alongside those developed by the bureaucracies and activists in the sphere of international development, notably the $2015 \mathrm{MDG}$ and water rights. Both of these are centred around access to safe drinking water, with MDG 7 Target Io calling, for instance, for the halving of the proportion of people without sustainable access to safe drinking water by 20I5. The Right to Water is codified in General Comment Is of the 2002 International Covenant on Economic, Social, and Cultural Rights (ICESCR), while the Human Right to Water was adopted by the United Nations General Assembly (UNGA) in Resolution A/RES/64/292 of 26 July 20Io, although not without opposition. These norms of equitable distribution, retribution, access, and sustainability for future generations are also reinforced directly and indirectly by various instruments of international law. 


\section{International law relevant to the impact of armed conflict on water infrastructure}

Research on the effects of war on water infrastructure has been led primarily by humanitarian aid agencies and practitioners. Water engineers have documented the impact of war on water infrastructure from Afghanistan to Angola (Nembrini, 200I, 2002), and highlighted the difficulties of partnering in external reconstruction efforts (Pinera and Reed, 2009). The Water and Habitat Department of the International Committee of the Red Cross (ICRC) is arguably the leading organisation in this field (see ICRC, I994, 2000, 2009).

The Department for International Law and Cooperation of the ICRC is exploring, furthermore, the limits of IHL — or the 'Geneva Conventions'-and protection of the environment in times of armed conflict (ICRC, 20IO), building on the work of the United Nations Environment Programme - as the United Nations Office for the Coordination of Humanitarian Affairs has done for infrastructure (UN-OCHA, 20I2). Tignino (2OIO) discusses the relevance of Article 52 (I) of the Geneva Convention's Additional Protocol I, ${ }^{\mathrm{I}}$ which calls for the 'protection of civilian objects which are not military objectives' by combatants. Based solidly on the tenet of non-discrimination (Pejic, 200I), Article 54 (Para. 2) and Article 55 of the same Protocol call for the 'protection of the natural environment' and 'objects indispensable to the survival of the civilian population' during times of armed combat (ICRC, I994; see also Hulme, 20Iо; Rieu-Clarke, Moynihan, and Magsig, 20I2, Table 6.2). Destruction of civilian water infrastructure in times of war is also considered to be a violation of the right to an adequate standard of living, as stated in the ICESCR (Article II (I)), ${ }^{2}$ as well as in the UNGA's Human Right to Water (Tignino, 20II), and in the United Nations Watercourses Convention (UNWC) of I997 (McCaffrey, 2007) - the latter is discussed in greater detail below.

In a similar way, the LBO states that the civilian population of territory occupied by an army 'must benefit from the maximal safeguards feasible in the circumstances' (Mason, 20I I, p. I), which extends to drinking and irrigation water infrastructure. ${ }^{3}$ Stein's (2OII) path-breaking work on 'waterfare' pushes the variety of laws to the limits, by linking the use of water as a weapon of war and exploring further the connections between the LBO, IHL, and IWL.

\section{International law and concepts relevant to the impact of armed conflict on water resources and trans-boundary water sharing}

The body of norms that have been developed concerning the impact of armed conflict on water resources is just as varied as the norms for water infrastructure. Flaws in the letter and the implementation of environmental law led in 2010 to a push by the United Nations Environment Programme (UNEP) and the United Nations Interregional Crime and Justice Research Institute for the legislation of 'environmental crime' (Higgins, 20IO). This may be the expression of a long-held (if abandoned) idea for the eradication of 'ecocide' (see, for example, Falk, I973). With future generations 
and environmental sustainability in mind, ecocide seeks to make 'extensive damage to, destruction or loss of ecosystem(s)' a ' 5 th crime against peace' (Eradicating Ecocide Global Initiative, 20I2). With fresh water as the lifeblood of all terrestrial ecosystems, armed conflict that damages water resources clearly would fall into this category or be an 'environmental crime'.

This developing body of environmental law can expect to face the same obstacles that confront all elements of international law (including lack of enforceability, capacity, and documentation), of course, as well as the additional challenge of a lack of an 'environmental baseline'. The issue is highlighted by post-war ecological studies of UNEP's investigation in Darfur, Sudan, of the relation between desertification and the fighting between government troops and militias (UNEP, 2007b), as well as by the environmental degradation caused by the Israeli attacks on Gaza in 2009 (UNEP, 2009). The challenge sparked the development of 'warfare ecology' by Machlis and Hanson (2008), who call for a more rigorous approach, meaning ecological evaluations at different stages of warfare (that is, during pre-war preparations, wartime, and post war). ${ }^{4}$ This would involve investigations at the local level to identify the destruction of crops and arable land, biodiversity loss, deforestation, and tactical oil spills. Post-war studies are advised to scrutinise long-term alterations in land use, biodiversity conservation in buffer zones, and long-term groundwater pollution (Machlis and Hanson, 2008).

Perhaps the most developed body of law on water resources is IWL. Developed from customary law (thus based on observation of state practice), IWL has been codified in a number of different instruments, notably the United Nations Economic Commission for Europe (UNECE)'s Water Convention of I992, the developing Draft Aquifer Articles of the International Law Commission, and the UNWC. Two of the three main principles of the UNWC are of direct relevance to this paper: 'no significant harm' calls for the minimisation of the impact of one state's activities on water resources in another state, while 'equitable and reasonable use' is the primary principle invoked for fair distribution of water resources between states (McCaffrey, 2007).

Of course, protection accorded to water infrastructure and water resources by these laws and norms during armed conflict remains, on the whole-as in the case at hand-theoretical. Not all parties consent to the norms, and international law cannot be readily enforced. A second equally important weakness is their blindness to the effect and influence that war can have on the management of water resources, or on trans-boundary water conflicts. One should note that wars can ravage formal and informal institutions (Cramer, 2006), just as they may be waged in (usually very small) part for the control of water resources (Allan, 200I).

\section{The analytical framework of water and armed conflict}

The 'analytical framework of water and armed conflict' presented here seeks to fill these gaps in research, and to employ elements of each aspect of international environmental norms and laws. It builds on the 'basis of conflict' in the Water Conflict Chronology (Gleick, 20II), which is used to classify war and water events from hydropolitical and military strategic perspectives, as shown in Table I. 


\section{Table 1. Water Conflict Chronology definitions}

\section{Key terms}

Control of water resources (state and non-state actors): where water supplies or access to water is at the root of tensions.

Military tool (state actors): where water resources, or water systems themselves, are used by a nation or a state as a weapon during a military action.

Political tool (state and non-state actors): where water resources, or water systems themselves, are used by a nation, state, or non-state actor for a political goal.

Military target (state actors): where water resource systems are targets of military actions by nations or states.

Terrorism (non-state actors): where water resources, or water systems, are either targets or tools of violence or coercion by non-state actors.

Development disputes (state and non-state actors): where water resources or water systems are a major source of contention and dispute in the context of economic and social development.

Source: Gleick (2011).

While the Water Conflict Chronology itself has been widely cited, there are few, if any, cases of direct application of the 'basis of conflict'. Its brief application to the 2006 Summer War has revealed a number of shortcomings, including, most importantly, the lack of reference to any international norms, or consideration of institutions or politics. There is also some duplication in the categories: 'terrorism', for instance, is distinguished from 'military tool' and 'military target' not by consequence of action but by the subjectively defined legitimacy of the actors responsible for the damage (actions carried out by a state are classed as a 'military tool' whereas those conducted by non-state actors are termed 'terrorism'). Finally, the classification discounts possible interpretation of the purpose of the acts, whether indiscriminate or discriminate. While intentionality may be difficult to prove, it is directly related to the nature of the attacks and thus to IHL, and is certainly of relevance to aspects of environmental justice and to conflict resolution efforts.

A much broader frame has been developed by Donnelly et al. (2012), in relation to water risks to businesses during times of war. Usefully, it distinguishes between the primary and the secondary impacts of hostilities. The 'analytical framework of water and armed conflict' shown in Table 2 reflects this broadening, and allows for deeper investigations by grounding impacts in international environmental norms and laws. The framework is built on the authors' humanitarian experience of assisting local authorities in supplying water and repairing water infrastructure during and following armed conflict throughout Africa, Asia, and the Middle East. ${ }^{6}$

The most relevant international environmental norms, laws, and concepts are suggested in the right-hand column of Table 2 . The left-hand column suggests a guide with which to evaluate the character of the damage, with 'indiscriminate damage' defined as that arising from indiscriminate attacks, which IHL prohibits and defines as being 'those which are not directed at a specific military objective' (Henckaerts and Doswald-Beck, 2005, Rule I2), and which are akin to 'collateral damage'. 'Discriminate damage' is defined here as that arising from attacks with specific military 
Table 2. Analytical framework of water and armed conflict

\begin{tabular}{|c|c|c|c|}
\hline Character & Description & Example & $\begin{array}{l}\text { Norms/law/ } \\
\text { concepts }\end{array}$ \\
\hline \multicolumn{4}{|c|}{ Armed conflict and water infrastructure } \\
\hline Indiscriminate & $\begin{array}{l}\text { Damage owing to indiscriminate } \\
\text { attacks on water infrastructure that } \\
\text { disrupts the flow of water sources or } \\
\text { access to them by non-combatants } \\
\text { (that is, the water infrastructure is } \\
\text { not the main target). }\end{array}$ & $\begin{array}{l}\text { - Manholes or fire hydrants crushed } \\
\text { by normal heavy equipment traffic. } \\
\text { - Distribution network pipes } \\
\text { crushed (where exposed). } \\
\text { - Main or transmission lines cut off } \\
\text { or dug up as part of a road, with } \\
\text { the intention of disrupting traffic. } \\
\text { - Random shrapnel or bullet dam- } \\
\text { age to public water reservoirs or } \\
\text { rooftop tanks. } \\
\text { - Any of the above suffered during } \\
\text { general destruction of urban } \\
\text { neighbourhoods. }\end{array}$ & \multirow[t]{2}{*}{$\begin{array}{l}\text { IHL, LBO, } \\
\text { 'waterfare', } \\
\text { 'urbicide', } \\
\text { human rights } \\
\text { and other rights } \\
\text { to water }\end{array}$} \\
\hline Discriminate & $\begin{array}{l}\text { Damage owing to targeted attacks } \\
\text { on water infrastructure that disrupts } \\
\text { the flow of water sources or access } \\
\text { to them by non-combatants (that is, } \\
\text { water infrastructure is the target). }\end{array}$ & $\begin{array}{l}\text { - Manholes or fire hydrants crushed } \\
\text { - Bhen off-road, or by diggers. } \\
\text { crushed or cut-up (where buried). } \\
\text { - Main or transmission lines cut-off } \\
\text { or dug up. } \\
\text { - Piercing of storage structures } \\
\text { (such as public water reservoirs or } \\
\text { rooftop tanks). } \\
\text { - Looting of water-treatment facilities. } \\
\text { - Damage to supporting structures } \\
\text { (such as electrical networks and } \\
\text { water-treatment supply lines). } \\
\text { - Destruction of household reservoirs } \\
\text { and large dams, for instance. }\end{array}$ & \\
\hline \multicolumn{4}{|c|}{ Armed conflict and water resources } \\
\hline Indiscriminate & $\begin{array}{l}\text { Short- or long-term impact owing to } \\
\text { indiscriminate attacks, leading to } \\
\text { reduced quantity and quality of } \\
\text { water resources (that is, water } \\
\text { resources are not the target). }\end{array}$ & $\begin{array}{l}\text { - Contamination of surface or ground- } \\
\text { water due to oil spills from military } \\
\text { staging stations, for example. } \\
\text { - Contamination resulting from } \\
\text { damage to oil reservoirs, petrol } \\
\text { stations, and power transformers, } \\
\text { inter alia. } \\
\text { - Seepage from untreated waste- } \\
\text { water when plants abandoned for } \\
\text { security reasons. }\end{array}$ & \multirow[t]{2}{*}{$\begin{array}{l}\text { Environmental } \\
\text { crime, ecocide, } \\
\text { warfare ecology, } \\
\text { environmental } \\
\text { and social justice, } \\
\text { IWL }\end{array}$} \\
\hline Discriminate & $\begin{array}{l}\text { Short- or long-term impact owing to } \\
\text { targeted attacks, leading to reduced } \\
\text { quantity and quality of water resources } \\
\text { (that is, water resources are the target). }\end{array}$ & $\begin{array}{l}\text { - Contamination of surface or ground- } \\
\text { water resulting from tactical oil spills. } \\
\text { Destruction of crops and arable } \\
\text { land; seepage of untreated waste- } \\
\text { water following destruction of } \\
\text { wastewater treatment plants. } \\
\text { - Poisoning of water sources. }\end{array}$ & \\
\hline
\end{tabular}




\begin{tabular}{|c|c|c|c|}
\hline Character & Description & Example & $\begin{array}{l}\text { Norms/law/ } \\
\text { concepts }\end{array}$ \\
\hline \multicolumn{4}{|c|}{ Armed conflict and water sector institutions/development } \\
\hline Indiscriminate & $\begin{array}{l}\text { Indirect impact on water-sector insti- } \\
\text { tutions or development projects and } \\
\text { plans, including 'opportunity costs'. }\end{array}$ & $\begin{array}{l}\text { - Water development infrastructure } \\
\text { or institutional projects and plans } \\
\text { halted for security reasons. } \\
\text { - Lost opportunities because of } \\
\text { donor reluctance to reinvest. } \\
\text { - Damaged or stolen administrative } \\
\text { records. } \\
\text { - Water bills unpaid (or disruption } \\
\text { in billing services). } \\
\text { - Further breakdown of infrastruc- } \\
\text { ture owing to decreased operations } \\
\text { and maintenance-such as lack of } \\
\text { spares or staff (due to the security } \\
\text { situation). } \\
\text { - 'Brain-drain', as skilled staff leave } \\
\text { the country. }\end{array}$ & $\begin{array}{l}\text { Environmental } \\
\text { and social } \\
\text { justice, MDGs, } \\
\text { human rights } \\
\text { and other rights } \\
\text { to water }\end{array}$ \\
\hline Discriminate & $\begin{array}{l}\text { Direct impact on water-sector institu- } \\
\text { tions, or development projects and } \\
\text { plans. }\end{array}$ & $\begin{array}{l}\text { - Targeted destruction of projects } \\
\text { under construction. } \\
\text { - Replacement of local decision- } \\
\text { makers with those from the } \\
\text { occupying army. } \\
\text { - Reduction of capacity of mainte- } \\
\text { nance crews. }\end{array}$ & \\
\hline \multicolumn{4}{|c|}{ Armed conflict and trans-boundary water conflict/cooperation } \\
\hline Indiscriminate & $\begin{array}{l}\text { Impact of indiscriminate attacks, } \\
\text { leading to worsening technical or } \\
\text { political relations over existing trans- } \\
\text { boundary water arrangements. }\end{array}$ & $\begin{array}{l}\text { Cessation of joint trans-boundary } \\
\text { projects owing to a breakdown in } \\
\text { or a lack of trust at the broader } \\
\text { political level. } \\
\text { - Violations of agreed treaties. } \\
\text { - Establishment of coercive trans- } \\
\text { boundary water 'cooperative' } \\
\text { mechanisms. }\end{array}$ & $\begin{array}{l}\text { IWL, environ- } \\
\text { mental and } \\
\text { social justice }\end{array}$ \\
\hline Discriminate & $\begin{array}{l}\text { Impact of attacks directed at specific } \\
\text { military objectives, leading to wors- } \\
\text { ening technical or political relations } \\
\text { over existing trans-boundary water } \\
\text { arrangements. }\end{array}$ & $\begin{array}{l}\text { - Military damage to upstream } \\
\text { trans-boundary water resources } \\
\text { or infrastructure to prevent with- } \\
\text { drawals or diversions. } \\
\text { - Military activity leading to the } \\
\text { creation or maintenance of an } \\
\text { inequitable distribution of water } \\
\text { resources. } \\
\text { - Acquisition of territorial control } \\
\text { (and so direct control over trans- } \\
\text { boundary water resources). } \\
\text { - Targeted contamination of down- } \\
\text { stream trans-boundary water } \\
\text { resources. }\end{array}$ & \\
\hline
\end{tabular}

Source: authors (based on Zeitoun (2005); Gleick (2011); Donnelly et al. (2012)). 
objectives, signifying intentional or targeted destruction (and so relates to the 'tool' and 'target' aspects of the framework of Gleick (20II)). IHL's distinction of combatants and non-combatants is also made use of in the more specific definitions.

\section{Water and war during the 2006 Summer War}

This section applies the 'analytical framework of water and armed conflict' to the 2006 Summer War on both sides of the Israel-Lebanon border.

\section{Water and war in Israel in 2006}

The 2006 Summer War claimed the lives of 43 Israeli civilians and II9 soldiers, and injured 690 and displaced between 300,000 and 500,000 people. Hezbollah launched around 4,000 surface-to-surface ('Katyusha', and other) rockets, 90I of which landed in urban areas. More than 6,000 homes were hit, some 2,000 of which were completely destroyed. The direct and indirect cost of the war in Israel has been estimated at USD I.6 billion (Israel Project, 20II).

Apart from public documents, the extent of the damage has been investigated in private interviews and unpublished reports, provided primarily by the 'water file' of the Ministry of Foreign Affairs, and by the Director of International Relations of the Ministry of Environmental Protection. The documentation show how the wastewater infrastructure suffered the bulk of the war damage.

Perhaps the most dramatic impact of the war on the environment was the destruction of about I,300 hectares (I2,000 dunums) of forest and woodland by fire. The Ministry of Environmental Protection also reported that the wastewater treatment plant (WTP) in Safad 'suffered direct damage to the sludge treatment facility, to the pipes and to adjacent buildings' (IMEP, 2006). Approximately I4,000 cubic metres of sludge from the Naharia WTP was dumped in the sea, owing to a 'lack of sufficient security facilities', as the plant was (presumably) evacuated during the war. Furthermore, biogas was either burned off or released - because of incomplete construction, or a lack of maintenance during hostilities - from three WTPs, including some 700,000 cubic metres from the Haifa WTP, I00,000 cubic metres from the Karmiel WTP, and 70,000 cubic metres from the Naharia WTP (IMEP, 2006).

Given the limited accuracy of the Katyusha and other missiles used by Hezbollah, the damage may be classified as 'indiscriminate', according to the analytical framework of water and armed conflict, and a violation of the relevant clauses of IHL. The long-term ecological ramifications of the sewage spills suggest classification of 'environmental crime', although their localised impact also is noteworthy in this regard. There is no other evidence of any significant impact of the war on water infrastructure, institutions, or resources in Israel. In addition, there is nothing to suggest that the attacks were intended to conquer any of the Lebanese or Syrian land still occupied by Israel (Cheba'a Farms or Ghajar the Golan) or to secure the water that flows through it (Zeitoun et al., 2012) - thus there is nothing to suggest an apparent hydro-political motive or effect. 


\section{Water and war in Lebanon in 2006}

The 2006 Summer War claimed the lives of around I, Ioo Lebanese civilians and 280-500 armed combatants, and injured 3,700 civilians and displaced more than 900,000 people (Amnesty International, 2006; GoL, 2006a, 2006b). Israeli Air Force F-I6s and other jets flew some I5,500 sorties, while the Israeli Navy fired more than 2,500 shells at coastal targets and IDF ground artillery based in northern Israel fired thousands of rounds at South Lebanon. Anti-personnel cluster bombs were employed, whose dart-filled bomblets failed to explode in many cases, rendering in excess of 500 farm fields inoperable (UNMACC, 2007; Darwish, Farajalla, and Masri, 2009). Power transmission lines and main roadways were also put out of service, while the runway at Beirut-Rafic Hariri International Airport and roughly 90 highway overpasses and bridges were debilitated. Some 30,000 housing units were destroyed and more than I00,000 were damaged (UNHRL, 2006). Around I,800 hectares of woodland were affected by forest fires and damage to the coastal oil reservoir at Jiyeh resulted in I2-I5,000 tonnes of fuel flowing into the sea (UNDP, 2007, Table 6.I).

The direct damage is estimated at between USD I.8 and 3.6 billion, and the opportunity cost at about USD 8 billion (GoL, 2006a, 2006b). While placing an economic value on 'the environment' is fraught with error, of course, the total economic cost of environmental damage has been estimated at USD 730 million- not including the cost to public health of degraded water quality (World Bank, 2007).

As one would expect, water infrastructure and resources were not spared in the fighting. Table 3 contains a complete list of the damage to water infrastructure, institutions, and resources, as well as to water-related livelihoods. The bulk of the data on water infrastructure and resources is from the South Lebanon Water Establishment (SLWE), with which one of the authors worked extensively as a United Nations (UN) employee to document the damage. This information is supplemented by reports from a number of $\mathrm{UN}$ agencies ${ }^{7}$ and by the direct observations of the authors, each of whom was involved in the reconstruction effort during and immediately following the war.

An understanding of the nature of the damage is necessary to gain a better understanding of the relationship between water and the 2006 Summer War, and serves to complement the application of the 'analytical framework of water and armed conflict'.

\section{Damage to water infrastructure and resources in Lebanon ${ }^{8}$}

One result of the extensive damage documented in Table 3 was the disruption of the domestic water supply to dozens of villages in southern Lebanon, as well as in the Dahiya neighbourhood of Beirut. A United Nations Children's Fund (UNICEF) Situation Report noted, for example, that ' 60 percent of towns and villages in South Lebanon are without regular water supplies due to infrastructure damage to the pipe network, lack of electricity to power the pumps, and destroyed or damaged roof water tanks' (cited in USAID, 2006). In many cases, the water supply was interrupted indirectly - that is, through damage to the electricity network (such as the destruction of hundreds of high-voltage transformers) - forcing the operators of water 
Table 3. Damage to water infrastructure, resources, development efforts and hydropolitics, Lebanon, $2006^{9}$

\begin{tabular}{|c|c|c|c|c|}
\hline Item & Area & Comments & Character $^{\mathrm{a}}$ & References $^{b}$ \\
\hline \multicolumn{5}{|c|}{ Armed conflict and water infrastructure } \\
\hline Public water reservoirs & South & $\begin{array}{l}\text { Fifty-five public water reservoirs } \\
\text { partially or completely destroyed. }\end{array}$ & $\begin{array}{l}12 \text { discriminate; } \\
43 \text { indiscriminate }\end{array}$ & $\begin{array}{l}\text { GoL, 2006a; } \\
\text { SLWE, } 2006\end{array}$ \\
\hline \multirow[t]{3}{*}{$\begin{array}{l}\text { Public drinking water } \\
\text { systems }\end{array}$} & Nabatieh & Public wells. & Indiscriminate & $\begin{array}{l}\text { UNDP, } 2007 \text {, } \\
\text { Ch. } 9, \text { p. } 1\end{array}$ \\
\hline & Taibe & $\begin{array}{l}\text { Pumping station captured and } \\
\text { occupied by the IDF. }\end{array}$ & Discriminate & MDM, 2006 \\
\hline & Wazzani & $\begin{array}{l}\text { Reservoir and pumps at the booster } \\
\text { station partially destroyed. }\end{array}$ & Discriminate & $\begin{array}{l}\text { GoL, 2006a; } \\
\text { SLWE, } 2006\end{array}$ \\
\hline Village-level pumps & Lebanon & $\begin{array}{l}\text { Twenty pumps damaged or } \\
\text { destroyed in villages. }\end{array}$ & Indiscriminate & $\begin{array}{l}\text { GoL, 2006a; } \\
\text { SLWE, 2006; } \\
\text { Allès, } 2010\end{array}$ \\
\hline Artesian wells & South & Two artesian wells damaged. & Indiscriminate & $\begin{array}{l}\text { GoL, 2006a; } \\
\text { SLWE, } 2006\end{array}$ \\
\hline Distribution networks & Lebanon & $\begin{array}{l}\text { Destruction of numerous sections } \\
\text { of village distribution networks } \\
\text { through, inter alia, the use of } \\
\text { bulldozers (witnessed in the case } \\
\text { of Aita el Cha'ab). }\end{array}$ & $\begin{array}{l}\text { Mainly indiscrimi- } \\
\text { nate (Aita el Cha'ab } \\
\text { - discriminate) }\end{array}$ & $\begin{array}{l}\text { Sadeldeen, } \\
2009\end{array}$ \\
\hline Household infrastructure & Lebanon & $\begin{array}{l}\text { Tens of thousands of household } \\
\text { rooftop hot-water tanks penetrated } \\
\text { by shrapnel or bullets. }\end{array}$ & Indiscriminate & $\begin{array}{l}\text { GoL, 2006a; } \\
\text { SLWE, } 2006\end{array}$ \\
\hline Power supply & South & $\begin{array}{l}\text { Electrical transmission lines to } \\
\text { and distribution lines within most } \\
\text { villages (including to most well } \\
\text { pumps). Between } 199 \text { and } 725 \\
\text { high-voltage electrical transform- } \\
\text { ers destroyed. }\end{array}$ & Discriminate & $\begin{array}{l}\text { GoL, 2006a; } \\
\text { SLWE, 2006; } \\
\text { UNDP, } 2006\end{array}$ \\
\hline \multirow[t]{2}{*}{ Irrigation schemes } & $\begin{array}{l}\text { West } \\
\text { Beka'a } \\
\text { Qara'oun }\end{array}$ & $\begin{array}{l}\text { Parts of main irrigation canals } \\
\text { destroyed. }\end{array}$ & Discriminate & UNDP, 2006 \\
\hline & Qasmiyeh & $\begin{array}{l}\text { Parts of main irrigation canals } \\
\text { destroyed. }\end{array}$ & Discriminate & $\begin{array}{l}\text { GoL, 2006a; } \\
\text { SLWE, } 2006\end{array}$ \\
\hline \multicolumn{5}{|c|}{ Armed conflict and water resources } \\
\hline \multirow[t]{2}{*}{$\begin{array}{l}\text { Surface water and } \\
\text { groundwater }\end{array}$} & Beka'a & $\begin{array}{l}\text { Contamination of groundwater by } \\
\text { oil and fuel seepage from between } \\
22 \text { and } 47 \text { damaged petrol stations. } \\
\text { Petrol seepage into local ground- } \\
\text { water at at least five stations in } \\
\text { the Beka'a Valley. }\end{array}$ & & UNDP, 2007 \\
\hline & Lebanon & $\begin{array}{l}\text { Contamination of surface or ground- } \\
\text { water by damaged or destroyed } \\
\text { industrial sites (heavy metals, } \\
\text { volatile organics, for instance). }\end{array}$ & Indiscriminate & $\begin{array}{l}\text { (UNDP, 2007, } \\
\text { Ch. 9; UNEP, } \\
\text { 2007a) }\end{array}$ \\
\hline
\end{tabular}




\begin{tabular}{|c|c|c|c|c|}
\hline Item & Area & Comments & Character $^{\mathrm{a}}$ & References $^{b}$ \\
\hline & & $\begin{array}{l}\text { Contamination of groundwater by } \\
\text { seepage from between } 199 \text { and } \\
725 \text { high-voltage electrical trans- } \\
\text { formers, many of which contained } \\
\text { polychlorinated biphenyls (PCBs). }\end{array}$ & & \\
\hline Fisheries/coast & $\begin{array}{l}\text { Lebanon/ } \\
\text { coast }\end{array}$ & $\begin{array}{l}\text { Damage from oil spill caused by } \\
\text { the attack on the Jiyeh power } \\
\text { plant. }\end{array}$ & $\begin{array}{l}\text { Discriminate } \\
\text { Indiscriminate }\end{array}$ & $\begin{array}{l}\text { UNDP, 2007; } \\
\text { UNEP, 2007a }\end{array}$ \\
\hline \multicolumn{5}{|c|}{ Armed conflict and water-sector institutions/development } \\
\hline Dam works & Beka'a & $\begin{array}{l}\text { Damages of equipment at the } \\
\text { Hermel dam construction site on } \\
\text { the Al Assi River in the Beka'a } \\
\text { Valley. }\end{array}$ & Discriminate & $\begin{array}{l}\text { UNDP, 2007, } \\
\text { Ch. 6, p. 10; } \\
\text { UN-ESCWA } \\
\text { and BGR, } \\
\text { 2012, Table } 4\end{array}$ \\
\hline SLWE & Saida & $\begin{array}{l}\text { The effort to coordinate and } \\
\text { execute the reconstruction effort } \\
\text { delays the water-sector reform } \\
\text { plan of the newly established } \\
\text { institution. }\end{array}$ & Indiscriminate & $\begin{array}{l}\text { Personal com- } \\
\text { munication }^{c}\end{array}$ \\
\hline Fish farms & Beka'a & $\begin{array}{l}\text { Several fish farms were directly } \\
\text { hit and more than } 50 \text { per cent of } \\
\text { annual production was destroyed } \\
\text { ( } 305 \text { tons) - along tributaries of } \\
\text { the Litani and Al Assi Rivers. }\end{array}$ & Discriminate & $\begin{array}{l}\text { UNDP, 2007; } \\
\text { UNEP, 2007a }\end{array}$ \\
\hline Agriculture & South & $\begin{array}{l}\text { Between } 0.5 \text { and } 1.5 \text { million un- } \\
\text { exploded cluster bomblets render } \\
\text { more than } 500 \text { fields inaccessible. }\end{array}$ & $\begin{array}{l}\text { Discriminate, indis- } \\
\text { criminate }\end{array}$ & $\begin{array}{l}\text { UNMACC, } \\
2007 ; \\
\text { Darwish, } \\
\text { Farajalla, } \\
\text { and Masri, } \\
2009\end{array}$ \\
\hline \multicolumn{5}{|c|}{ Armed conflict and trans-boundary water conflict/cooperation } \\
\hline $\begin{array}{l}\text { Upper Jordan River } \\
\text { conflict }\end{array}$ & South & $\begin{array}{l}\text { Minor damage to the Wazzani } \\
\text { Pumping Station, the construc- } \\
\text { tion of which (in 2002) led to } \\
\text { high tension between Israel and } \\
\text { Lebanon, owing to the threat of } \\
\text { alteration of the asymmetric use } \\
\text { of the Hasbani tributary of the } \\
\text { Jordan River. As discussed in the } \\
\text { text, no hydro-political motive for } \\
\text { the damage is apparent. }\end{array}$ & Indiscriminate & $\begin{array}{l}\text { Zeitoun et } \\
\text { al., 2013; } \\
\text { Zeitoun, } \\
\text { Talhami, and } \\
\text { Eid-Sabbagh, } \\
2013\end{array}$ \\
\hline Al Assi/Orontes & North & $\begin{array}{l}\text { Damage to the dam site on the } \\
\text { tributaries of the Al Assi River } \\
\text { might have affected the } 2002 \\
\text { Syria-Lebanon Treaty, although } \\
\text { no significant impact has been } \\
\text { observed. }\end{array}$ & Indiscriminate & \\
\hline
\end{tabular}

a Character here reflects the authors' assessment, according to the definition of indiscriminate and discriminate damage in the main text.

b See also http://www.rebuildlebanon.gov.lb.

c Interview with Ahmad Nizam, the Director of the SLWE, Saida, Lebanon, 5 March 2011. 
pumps to use back-up diesel electricity generators. Diesel fuel for generators, however, is also a link in the water-supply chain, and was in short supply because of damage to the roads, the destruction of fuel stations, and fear of personal injury during delivery of relief fuel.

Direct damage to water infrastructure was the product of tank traffic, light-arms shrapnel, or fire from rifles, tanks, and fighter jets. It took the form of partially or completely destroyed water pumping stations, transmission mainlines and distribution network lines, pumps for elevated reservoirs, networks within villages, underground household rainwater catchment cisterns, pumps to convey water to rooftop reservoirs, household rooftop reservoirs, and larger municipal water reservoirs. ${ }^{\text {Io }}$ Most of the damage to pipelines and roof tanks appears in general to have been 'indiscriminate', in the sense that it was the outcome of shelling of neighbourhoods for military purposes. The damage to public water reservoirs and to the Wazzani pumping station warrant closer attention (see below).

The war also affected the SLWE, which had been established just one year prior to the war. The crisis for which the new institution found itself responsible halted the sector reforms that were under way, for the entire recovery and reconstruction period (Allès, 20IO). The cost to the SLWE of providing alternative sources of water and of repairing the damaged infrastructure has been estimated at USD I30 million (World Bank, 2007), while SLWE operations were also caught up directly and indirectly in the internal political tensions that ensued from the war ${ }^{\mathrm{II}}$ (Allès, 2007, 2010).

The post-war environmental assessments prepared by UNEP (2007a) and the United Nations Development Programme (UNDP, 2007) highlight a number of threats to and impacts on the environment, specifically water resources. The lack of baseline data makes it difficult to gauge their significance, though, and it is a complex task to distinguish between war-induced and chronic sources of pollution of water resources.

The most obvious harmful environmental effects of the war- notwithstanding the Jiyeh oil spill — are considered to originate from damaged and destroyed industrial sites, damaged petrol stations, and damaged electricity transformers. ${ }^{12}$ Groundwater ${ }^{13}$ was particularly vulnerable to the effects of oil and fuel seepage from damaged petrol stations (estimated to number between 22 and 47 in South Lebanon and the Beka'a Valley). The risk of contamination was believed to be highest in the Beka'a Valley, because of the aquitard and other structures in the Eocene geological substrata. ${ }^{\mathrm{I}}$ The destruction of roughly 200-700 high-voltage electricity transformers also posed a particular risk because of the potential seepage into the groundwater of polychlorinated biphenyls (PCBs) (UNDP, 2007, Table I and ch. 9, p. 5). The carcinogenic compounds have a very long retention time, spreading the risk to future generations, and contravening the norms being developed by ecocide and environmental justice.

No information on damage of WTPs - in terms of released sludge or biogas owing to the fleeing of maintenance teams, as occurred in Israel-has been documented. It is reasonable to assume, though, that this type of damage was minor in relation to that suffered south of the border (since there are fewer large WTPs), as well as to the rest of the damage in Lebanon. 


\section{Damage to public water reservoirs and the impact on the Jordan River conflict}

The most visible impact of the war was on public water reservoirs. The distribution of damaged water reservoirs (see Figure I) reflects the level of fighting. ${ }^{\text {Is }}$ The nature of the damage to the reservoirs varies, as Médecins du Monde (MDM, 2006, p. 30) notes:

Water supply through the public water networks ceased from the outbreak of the conflict. Where the municipal reservoirs were elevated, they were usually damaged by bombing. It is difficult to establish whether the damage was deliberate, as in some cases even their highly visible position far from the village suggests the acts were intentional. In the rare

Figure 1. IDF-related damage to public water reservoirs in Lebanon during the 2006 war

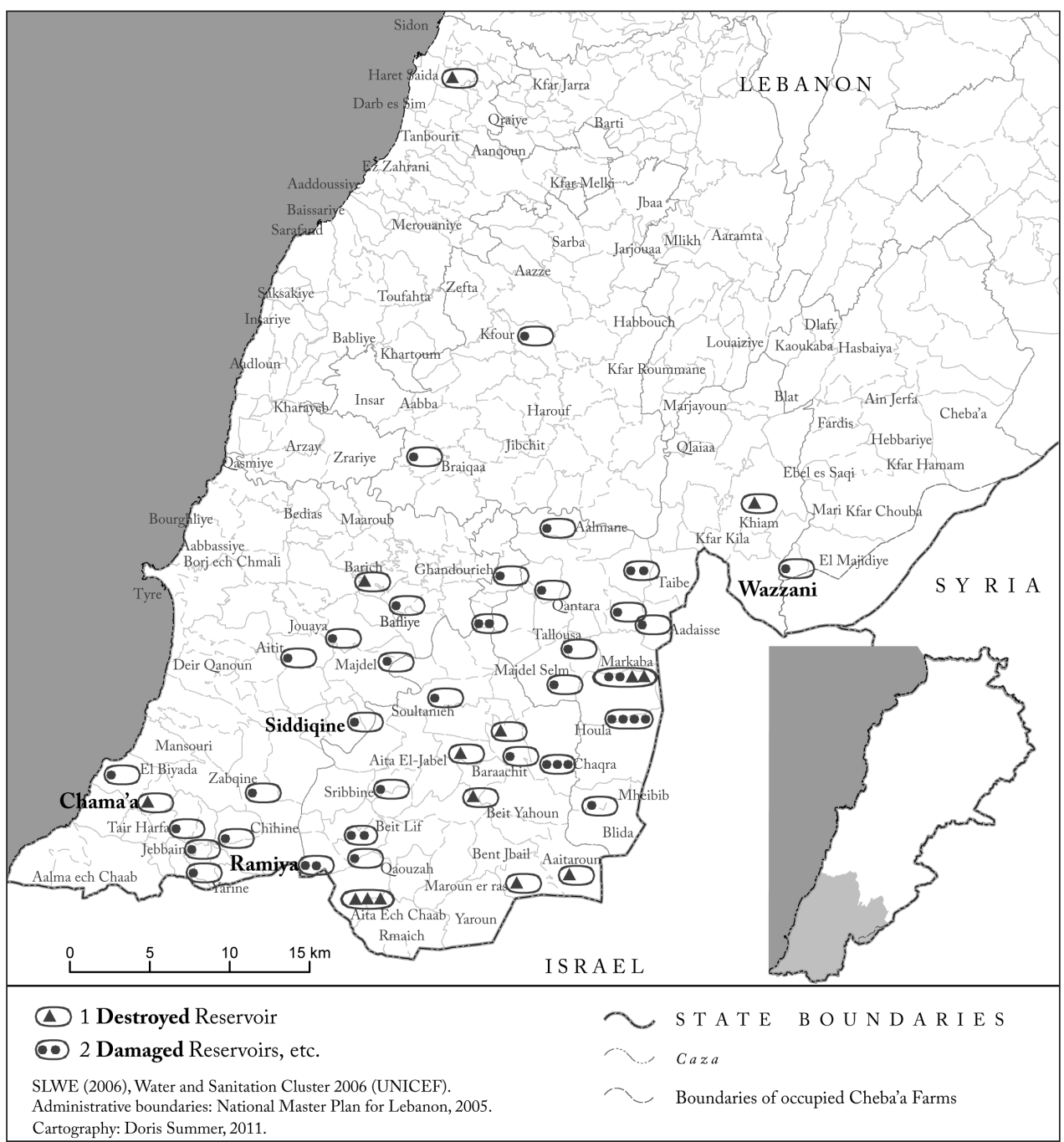

Notes: the towns in bold are discussed in the text. Villages listed that did not suffer damage to reservoirs experienced mild-to-severe damage to other infrastructure.

Source: Zeitoun et al. (2012). 
cases where reservoirs were spared from damage, or were buried, it was the water distribution networks under bombed roads that were damaged (translation by the authors).

A closer look at the three reservoirs shown in Figure 2 provides further insight into the character of the damage. The elevated reservoir in Siddiquine is typical of the design of water towers in the region. It is located on the village limits right beside its feeder well, and it remained intact even as the village centre was struck by Israeli artillery and air strikes. Any direct damage to the reservoir is superficial (due to

Figure 2. Sample of water reservoirs in Lebanon that suffered different types of damage during the 2006 war

a) Siddiquine reservoir:

no direct damage to reservoir

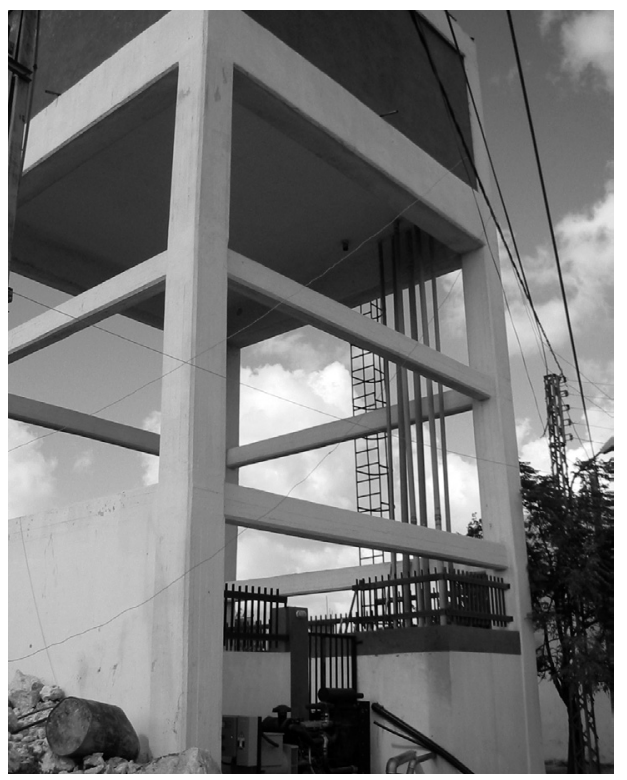

b) Chama'a reservoir:

'indiscriminate' and 'discriminate'

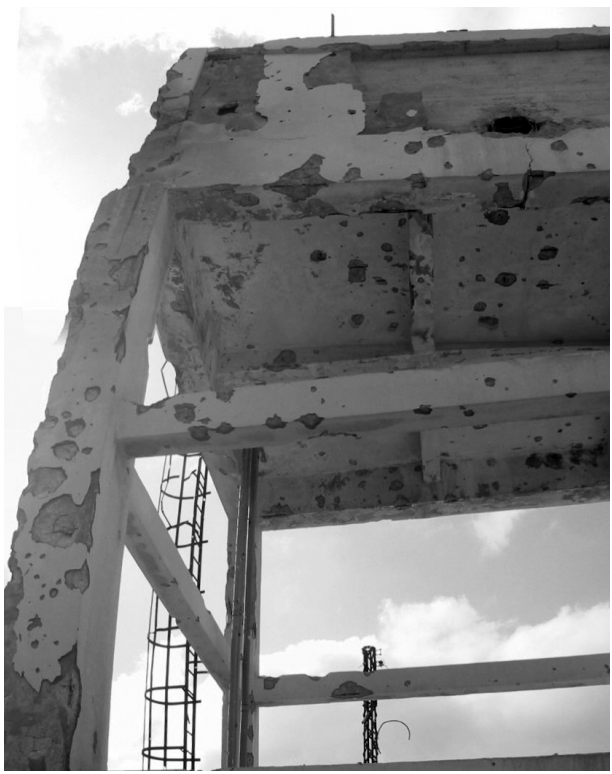

c) Ramiya reservoir: 'discriminate'

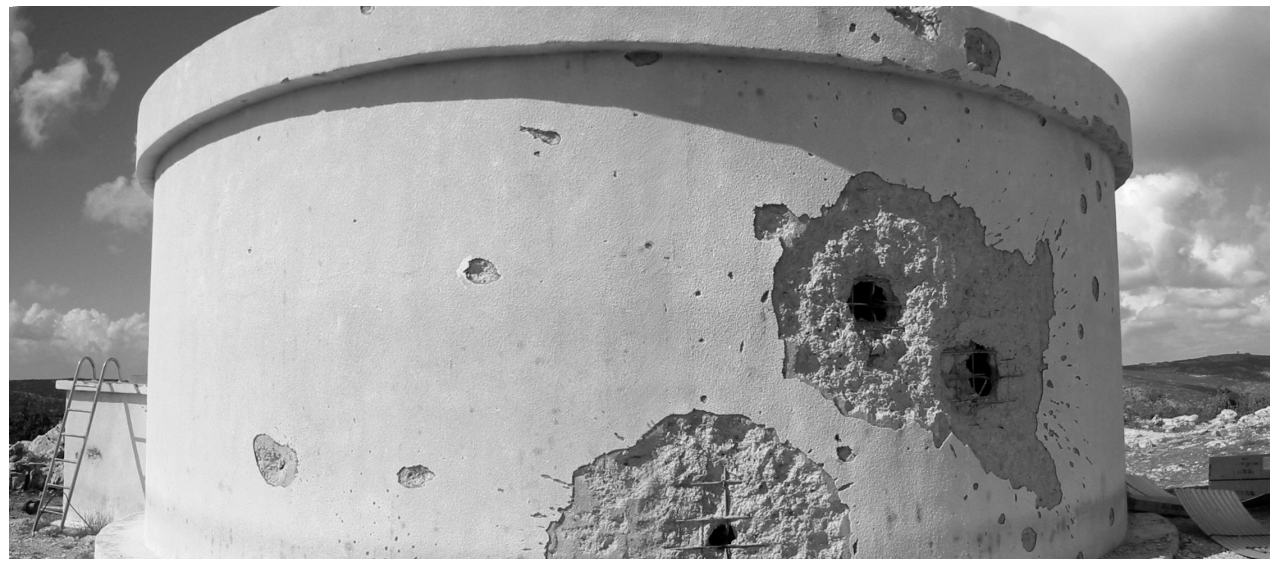

Source: authors. 
shrapnel), and can be classified as indiscriminate. However, the water supply of residents who remained in the town ceased because of damage to the electrical mains that powered the pump feeding the reservoir. The new mobile electricity generator shown in the photograph is a replacement of the original backup generator that was decommissioned by the same shrapnel (and in any case probably had not been maintained adequately). The water supply to the villagers was interrupted therefore without direct damage to the water storage infrastructure. Once the fighting had stopped and the security of rehabilitation crews was assured, the backup generator was replaced and the well and reservoir quickly became functional.

The Chama'a reservoir was hit by multiple types of projectiles, shrapnel, bullets, and at least one tank or fixed artillery round. The nature of the damage reflects the reservoir's highly exposed location: on the edge of the town at the top of a hill that overlooks a valley marking the northern border of Israel. The damage inflicted may be classed as either indiscriminate or discriminate, depending on whether the reservoir was used by combatants as a vantage point or to store weapons. ${ }^{6}$ No quick restoration of the reservoir was possible, necessitating the construction of temporary 'Oxfam' water tanks to restore partially water delivery services to the town, along with the delivery of a temporary diesel electricity generator.

Unlike the two previous examples, the Ramiya reservoir sits on the ground on a hill, slightly removed from the village. It does not show the same signs of intense fighting or shelling, but it suffered three very targeted higher-calibre hits, probably tank shells. The town's other public reservoir (which is elevated) was also very heavily damaged. As with the Chama'a reservoir, the damage may be judged to be both indiscriminate and discriminate. Water delivery could only be restored in part after the cessation of hostilities through the construction of a temporary reservoir and power supply.

The least visible impact of the war was on the politics of the Upper Jordan River conflict, which may be explored by examining the elevated reservoir of the booster station of the Wazzani Pumping Station (see Figure 3). The reservoir suffered apparently targeted structural damage, while the pump, the electricity supply, and the underground transmission pipes of the pumping station itself were damaged to a lesser degree (Zeitoun et al., 20I2). Damage to this municipal reservoir raises the question of ulterior (hydro) political motives, as its construction by the Government of Lebanon in 2002 nearly sparked a war itself - known as the Wazzani Springs dispute (Maternowski, 2006; Allès, 2007). The construction was a challenge to the inequitable sharing of the flows that had been established by Israel in I964 (Amery, 2000; Zeitoun et al., 20I3).

An unconsidered interpretation of the motives behind the damage would suggest that it was inflicted by the IDF to prevent further abstractions from the Springswhich the Government of Israel failed to do through diplomacy in 2002. The partial destruction of the reservoir indeed interrupted the water supply to villages fed by the pumping station, but left the object of the 2002 water conflict - the abstraction pumps - relatively intact. The damage to the reservoir (and to the pumping station 
Figure 3. Wazzani Pumping Station Reservoir

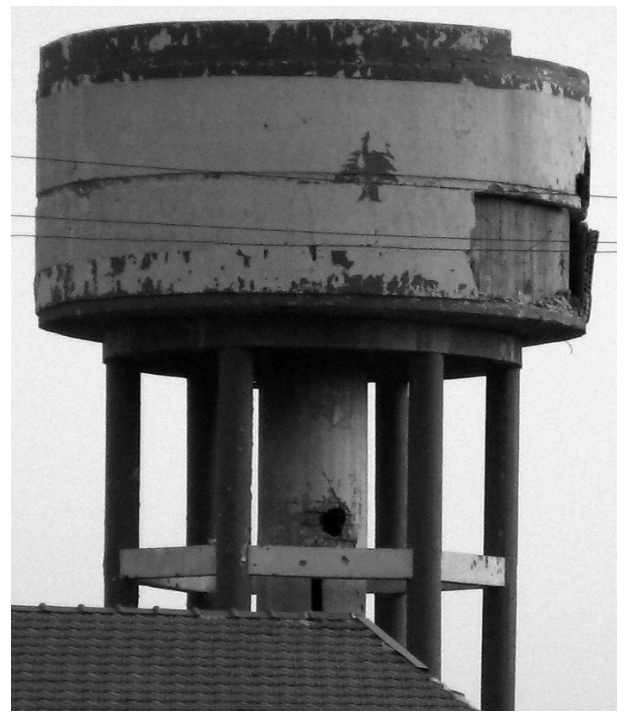

Source: authors. itself) was less severe than that to many of the other reservoirs, although it would have been a simple task for the Israeli Air Force or ground troops to put the abstraction pumps out of commission. At the end of the war, the minor structural damage was repaired, and the pumping station resumed operations some months later.

The extent of the damage caused to the Wazzani reservoir suggests that, whether targeted or indiscriminate, it was not intended to stop Lebanese long-term water withdrawals, and thus was not directly linked to the Israel-Lebanon conflict over the Upper Jordan River. The Government of Lebanon has not attempted any further development of the river since 2002, suggesting that the 2006 attacks have served to shore-up 'remote control' of

the trans-boundary resource, by pre-empting any further Lebanese development (Zeitoun et al., 2013).

\section{Discussion: violations of international law and norms}

The discriminate or indiscriminate damage by the Government of Israel of more than 5o Lebanese public water reservoirs begs the question whether it was part of official army policy. Reflecting on the subject, Israeli academic Hillel Shuval proposes that the blame resides with individual soldiers: 'It was not a war tactic but rather disgraceful acts by soldiers as an act of vengeance or retaliation to attacks around these infrastructures' (original emphasis). The viewpoint is supported by a statement from an Israeli spokesperson for the Ministry of Foreign Affairs: 'there's a policy decision at the highest level not to target those water pumping stations' (Murphy 2006). Having dealt with previous damage during the Israeli invasions in 1993 and I996, however, Ahmad Nizam, the Director of the SLWE, asked how the damage could be anything but targeted, whether or not it was official military policy. ${ }^{17}$

In any case, the destruction of such vital services is a well-known method of clearing civilians during fighting, and of preventing or delaying their return to their homes. The damage to the reservoirs and to the rest of the water infrastructure is also clearly a violation of IHL (which calls for the protection of the 'natural environment' and of 'objects indispensable to the survival of the civilian population'). In addition, the disruption of water services plainly breaches the right to water (as detailed in the ICESCR and UNGA Resolution A/RES/64/292), and is an issue of access that may result in a deep sense of injustice, and calls for retribution. 
Classification of the damage inflicted on groundwater in Lebanon as an 'environmental crime' would require further investigation of the effect on wider ecosystems. The long-term nature of some damage certainly invokes, and could be expected to be perceived as, environmental injustice. The damage to rural water-based livelihoods would seemingly illicit a similar sense of injustice, and along with the damage to water institutions in Lebanon, is a setback for the state in meeting its MDGs. The limited Israeli damage to the Wazzani Pumping Station has been interpreted as mildly reinforcing asymmetric distribution of control over the Upper Jordan River, which thus remains in contravention of the IWL principle of 'equitable and reasonable' use. It also suggests no hydro-political motive for the war.

\section{Conclusion}

Gregory (20I0, p. I54) emphasises how 'new' wars may be cast as 'surgical, sensitive, and scrupulous'. The evidence of destruction of civilian infrastructure-let alone civilian causalities - reveals that there was nothing 'new' about the 2006 Summer War. It was evidently indiscriminate, callous, and predatory, as most wars tend to be. The relationship demonstrates less of the rich reproductive tendencies reviewed by Pearson (2OI2) than a uni-directional impact of war on water (infrastructure, institutions, politics, and resources). This may not be the case in more protracted armed conflicts (such as Iraq), or in drier (such as Libya) or wetter (such as Sri Lanka) climes.

Application of the 'analytical framework of water and armed conflict' has revealed some of its methodological and analytical weaknesses. A judgement of the character of the damage can tend towards subjectivity, among other things, and is best handled by combat and munitions experts familiar with the military engagement (as was the case with the UN Human Rights Council's investigation into the 2008-09 offensive in Gaza) (UNHRC, 2009). In addition, given the very wide range of short- and long-term direct and indirect links between armed conflict and the environment, the lack of solid pre-war environmental baselines also weakens the utility of postwar assessments. Here, the call of Machlis and Hanson (2008) for deeper ecological investigations at all stages rings true, even if they are not likely to be high on any government's policy priority list. Furthermore, although the authors have benefitted from their personal experience of the case at hand, the data-collection methods are difficult to replicate. Perhaps most importantly, the tallying of damage is very distant from the human cost of war, and while debates rage over its enduring effect on ecology, this research approach does little to address directly the mental and the physical health of future generations. Subsequent examinations of the relationship between water and armed conflict would do well to gauge the impact-direct and cumulative-on people.

Nevertheless, the framework has served to broaden and deepen existing methods to explore the water-war relationship, identifying explicitly the nature of acts of war (indiscriminate or discriminate), and grounding them in international water norms and law. The framework can be used as well to provide the empirical evidence 
required to refine and reinforce the international environmental legal framework. Here, the environmental activist forces (including those developing the laws to criminalise 'ecocide') and the physical scientists advocating warfare ecology may combine with the international law community to develop rules of war, as well as international norms during periods of non-war.

A role for international humanitarian organisations at every stage of an armed conflict also is identified. Budget constraints make the establishment of environmental baselines prior to a war very difficult to justify, although the capacity to document damage before, during, and after hostilities exists. Its execution by water and sanitation engineers and project managers would aid progressive social agendas aimed at protecting all aspects of water/environment/people in future armed conflicts. And the now well-established post-conflict environmental damage assessments could be assisted by the framework's anchoring of international environmental and water norms and laws. While a cynical view of the efficacy and enforceability of international norms and law might judge such efforts as futile, their contribution through norm-building and 'soft law' should not be discounted.

\section{Correspondence}

Mark Zeitoun, Water Security Research Centre, School of International Development, University of East Anglia, Norwich NR4 7TJ, United Kingdom.

E-mail:m.zeitoun@uea.ac.uk

\section{Endnotes}

I Adopted on 8 June 1977, as an addition to the Geneva Conventions of I949.

2 See also General Comment Is of the United Nations Committee on Economic, Social, and Cultural Rights (http://www.unhchr.ch/tbs/doc.nsf/o/a5458didibbd7I3fcI 256cc400389e94).

3 The growing literature on 'urbicide' goes somewhat further in examining the impact of armed conflict on infrastructure, by analysing the reasons behind patterns of destruction of the built environment (Coward, 2008).

4 Machlis and Hanson (2008, Table I) expand the scale of examination to consider the impact of war on the local landscape and on regional and global ecosystems.

5 A more helpful definition could be: 'Water terrorism (state and non-state actors) - where water resources or water systems are employed as either targets or tools to create fear and panic in the opponent's civilian population'.

${ }^{6}$ Improvements and modifications based on experience of other wars is welcome.

7 Nonetheless, the full extent of the damage cannot be ascertained with great certainty, as it was not documented in a standardised or systematic way.

8 This stocktaking of damage does not include air and soil pollution owing to increased quarrying activity to support the reconstruction, forest fires, or the Jiyeh oil spill.

9 Damage in Beirut and undocumented damage is not included. Only damage that has been documented and can be referenced is listed here, although the authors acknowledge the existence of considerable undocumented damage, particularly in Beirut. 
Io As coordinator of water and sanitation relief efforts, UNICEF compiled an incomplete list of damage to water infrastructure (available on request from the authors).

II The reconstruction effort saw several political factions and other groups engage in classic postwar distributive politics, something relatively well-documented by government ministries and international aid agencies (Eid-Sabbagh, 2007; Darwish, Farajalla, and Masri, 2009; Hamieh and Mac Ginty, 20I0).

I2 The soil of the Choueifat industrial area, for example, was contaminated by the ash fall-out resulting from damage to $\mathrm{I} 3$ sub-plots, including the Transmed compound that stored lead batteries and household cleaning products, which was hit by a 'bunker buster' (UNDP, 2007, Ch. 9, p. I).

I3 Surface water was also contaminated. Heavy metals and volatile organics were found in the Ghadir stream, complementing BOD (biological oxygen demand) and COD (chemical oxygen demand) readings that were between two and seven times more than the regulatory limits (UNEP, 2007a, pp. II8-I25).

${ }^{14}$ The karst limestone aquifer predominant throughout South Lebanon (including in the Hasbani/ Wazzani basin, the flashpoint of hydro-politics as will be shown below) is more resilient to benzene seepage, as toxins would be flushed away relatively easily by winter rains (UNDP, 2007, p. 96).

Is Establishing patterns between the extent of the destruction of all civilian infrastructure (including bridges and houses) and the destruction of the public water reservoirs in particular is difficult. Not all of the damaged reservoirs were located in villages that saw heavy fighting. The reservoir in Aalmane was destroyed, for example, although 'only' three houses were destroyed or severely damaged in the village. Most of the damaged reservoirs appear to be situated in villages where the general level of destruction was high, and which witnessed ground fighting on a more or less intense scale (the reservoirs in Ba'albeck and Haret el Saida excepted). Around 60 reservoirs that were in the line of fire were not touched.

I6 We consider the use of the reservoir in this manner to be unlikely, given the stealth nature of the fighting, but a definitive conclusion requires much further investigation of the nature of the hostilities.

${ }^{17}$ Interview with the authors, Saida, Lebanon, 5 March 20 I.

\section{References}

Achcar, G. and M. Warschawski (2007) The 33-Day War: Israel's War on Hezbollah in Lebanon and its Aftermath. Saqi Books, London.

Allan, J.A. (200I) The Middle East Water Question: Hydropolitics and the Global Economy. I.B. Tauris, London.

Allès, C. (2007) 'La question du retour de l'État libanais dans l'ancienne zone occupée par Israël. L'exemple du bassin versant du Hasbani-Wazzani'. Universite lumière Lyon II, Lyon.

Allès, C. (20I0) 'La réforme du secteur de l'eau au Liban-Sud face à l'urgence de la reconstruction après la guerre de juillett 2006'. Geocarrefour. 85(2). pp. I4I-I5I.

Amery, H. (2000) 'A popular theory of water diversion from Lebanon: toward public participation for peace'. In A. Wolf and H. Amery (eds.) Water in the Middle East: A Geography of Peace. University of Texas Press, Austin, TX. pp. I2I-I49.

Amnesty International (2006) Israel/Lebanon: Out of All Proportion-Civilians Bear the Brunt of the War. AI Index:MDE 02/033/2006.http://news.bbc.co.uk/I/shared/bsp/hi/pdfs/2I_II_O6_amnesty.pdf (accessed on II November 2013).

Coward, M. (2008) Urbicide: The Politics of Urban Destruction. Routledge, London.

Cramer, C. (2006) Civil War is Not a Stupid Thing. Hurst \& Co. (Publishers) Ltd., London.

Darwish, R., N. Farajalla, and R. Masri (2009) 'The 2006 war and its inter-temporal economic impact on agriculture in Lebanon'. Disasters. 33(4). pp. 629-644. 
Donnelly, K., M.-L. Ha, H. Cooley, and J. Morrison (2012) Water as a Casualty of Conflict: Threats to Business and Society in High-Risk Areas. Pacific Institute, Oakland, CA.

Eid-Sabbagh, K. (2007) Reconstruction in Lebanon: Neoliberalism and Spatial Production. American University of Beirut, Beirut.

Eradicating Ecocide Global Initiative (20I2) 'What is ecocide'. http://eradicatingecocide.com/ overview/what-is-ecocide/ (accessed on I5 December 20I2).

Falk, R.A. (I973) 'Environmental warfare and ecocide - facts, appraisal, and proposals'. Security Dialogue. 4(I). pp. 80-96.

Gleditsch, N.P., K. Furlong, H. Hegre, B. Lacina, and T. Owen (2006) 'Conflicts over shared rivers: resource scarcity or fuzzy boundaries?'. Political Geography. 25(4). pp. 36I-382.

Gleick, P. (20I I) Water Conflict Chronology. Pacific Institute, Oakland, CA.

GoL (Government of Lebanon) (2006a) Lebanon: On the Road to Reconstruction and Recovery. GoL, Beirut.

GoL (2006b) Setting the Stage for Long Term Reconstruction: The National Early Recovery Process, 2006. GoL, Beirut.

Goodman, G., I. Menuchin, and A. Oron (2009) No Second Thoughts: The Changes in the Israeli Defense Forces' Combat Doctrine in Light of 'Operation Cast Lead'. Public Committee Against Torture in Israel, Jerusalem.

Gregory, D. (2010) 'War and peace'. Transactions of the Institute of British Geographers. 35(2). pp. I54-I86.

Hamieh, C.S. and R. Mac Ginty (20IO) 'A very political reconstruction: governance and reconstruction in Lebanon after the 2006 war'. Disasters. 34(SI). pp. Sio3-Si23.

Henckaerts, J.-M. and L. Doswald-Beck (2005) Customary International Humanitarian Law - Volume I: Rules. Cambridge University Press, Cambridge.

Higgins, P. (20I0) Eradicating Ecocide: Laws and Governance to Stop the Destruction of the Planet. ShepheardWalwyn (Publishers) Ltd., London.

Hiskes, R.P. (2006) 'Environmental human rights and intergenerational justice'. Human Rights Review. 7(3). pp. $8 \mathrm{I}-95$.

Hulme, K. (20I0) 'Taking care to protect the environment against damage: a meaningless obligation?'. In ICRC (ed.) International Review of the Red Cross. 92 (879). ICRC, Geneva. pp. 675-69I.

ICRC (International Committee of the Red Cross) (I994) Handbook of the International Red Cross and Red Crescent Movement - International Humanitarian Law. ICRC, Geneva.

ICRC (2000) 'Water, wars and humanitarian futures'. In ICRC (ed.) War and Water. ICRC, Geneva. ICRC (2009) Water and War. ICRC, Geneva.

ICRC (ed.) (2010) 'Environment'. International Review of the Red Cross. 92 (879). ICRC, Geneva. http://www.icrc.org/eng/resources/international-review/review-879-environment/index.jsp (accessed on I6 November 20I3).

IMEP (Israeli Ministry of Environmental Protection) (2006) Damage to Wastewater Treatment Facilities After the Second Lebanon War 2006. IMEP, Jerusalem. (In Hebrew.)

Israel Project (20II) 'The Hezbollah-Israel conflict: by the numbers'. Israel Project, Washington, DC.

Julien, F. (2OI2) 'Hydropolitics is what societies make of it (or why we need a constructivist approach to the geopolitics of water)'. International Journal of Sustainable Society. 4(I-2). pp. 45-7I.

Le Billon, P. (200I) 'The political ecology of war: natural resources and armed conflicts'. Political Geography. $20(5) \cdot$ pp. 56I-584.

Machlis, G.E. and T. Hanson (2008) 'Warfare ecology'. Bioscience. 58(8). pp. 729-736.

Mason, M. (20II) 'The application of warfare ecology to belligerent occupations'. In G. Machlis et al. (eds.) Warfare Ecology: A New Synthesis for Peace and Security. Springer, Dordrecht. pp. I55- I73.

Maternowski, E. (2006) Die Wasserverteilungsproblematik zwischen Israel und Libanon am Beispiel des Hasbani/Wazzani Konflikts. University of Potsdam, Potsdam.

McCaffrey, S. (2007) The Law of International Watercourses. Oxford University Press, Oxford. 
MDM (Médecins du Monde) (2006) Les Conséquences du Conflit de l'été 2006 sur les Conditions de Vie et la Santé des Populations civiles du Sud-Liban. MDM, Paris.

Murphy, K. (2006) 'Old feud over Lebanese river takes new turn'. The Los Angeles Times. Io August. http://articles.latimes.com/2006/aug/Io/world/fg-litaniı (accessed on I I November 20I3).

Nembrini, P.G. (200I) Huambo (Angola): Water Supply in a War-torn Town: Evolution and Impact of the Different Interventions since 1985. Occasional Paper. 3. Geneva Foundation, Geneva.

Nembrini, P.G. (2002) Kabul Water Supply: Evolution Since the 1992-94 Civil War. Occasional Paper. 7. Geneva Foundation, Geneva.

Pearson, C. (2012) 'Researching militarized landscapes: a literature review on war and the militarization of the environment'. Landscape Research. 37(I). pp. II5-I33.

Pejic, J. (200I) 'Non-discrimination and armed conflict'. International Review of the Red Cross. 83(84I). pp. I83-I94.

Peluso, N.L. and P. Vandergeest (20I I) 'Political ecologies of war and forests: counterinsurgencies and the making of national natures'. Annals of the Association of American Geographers. Ior (3). pp. 567-608.

Pinera, J.-F. and R. Reed (2009) 'A tale of two cities: restoring water services in Kabul and Monrovia'. Disasters. 33(4). pp. 574-590.

Rawls, J. (197I) A Theory of Justice. Harvard University Press, Cambridge, MA.

Rieu-Clarke, A., R. Moynihan, and B.-O. Magsig (20I2) UN Watercourses Convention: User's Guide. Centre for Water Law, Policy, and Science, University of Dundee, Dundee.

Sadeldeen, A.S. (2009) Ways of Action During the Post War Reconstruction in a Lebanese Southern Village. M.U.P.P. Thesis. Department of Architecture and Graphic Design, American University of Beirut, Beirut.

Schlosberg, D. (2004) 'Reconceiving environmental justice: global movements and political theories. Environmental Politics. I3(3). pp. 517-540.

Sen, A. (2009) The Idea of Justice. Harvard University Press, Cambridge, MA.

SLWE (South Lebanon Water Establishment) (2006) Damage to the Water Sector in the South of Lebanon from the 2006 War. SLWE, Saida.

Stein, J.D. (20I I) 'Waging Waterfare: Israel, Palestinians, and the Need for a New Hydro-Logic to Govern Water Rights under Occupation'. New York University Journal of International Law and Politics. 44(I). pp. I65-2I8.

Tignino, M. (2010) 'Water, international peace, and security'. In ICRC (ed.) International Review of the Red Cross. 92 (879). ICRC, Geneva. pp. 647-674.

Tignino, M. (20II) 'The right to water and sanitation in post-conflict peacebuilding'. Water International. 36(2). pp. 242-249.

UN-ESCWA (United Nations Economic and Social Commission for Western Asia) and BGR (Bundesanstalt für Geowissenschaften und Rohstoffe) (20I2) ‘Orontes River Basin'. In UN-ESCWA (ed.) Inventory of Shared Water Resources in Western Asia. UN-ESCWA and BGR, Beirut. pp. I69-222.

UN-OCHA (United Nations Office for the Coordination of Humanitarian Affairs) (20I2) How Dispossession Happens: The Humanitarian Impact of Palestinian Water Springs by Israeli Settlers. Special Focus March 20I2. UN-OCHA, East Jerusalem.

UNDP (United Nations Development Programme) (2006) UNDP's Participation in Lebanon's Recovery in the Aftermath of the July 2006 War. UNDP, Beirut.

UNDP (2007) Lebanon: Rapid Environmental Assessment for Greening Recovery, Reconstruction and Reform. UNDP, Beirut.

UNEP (United Nations Environment Programme) (2007a) Lebanon: Post-Conflict Environmental Assessment. UNEP, Nairobi.

UNEP (2007b) Sudan: Post-Conflict Environmental Assessment. UNEP, Nairobi.

UNEP (2009) Environmental Assessment of the Gaza Strip following the Escalation of Hostilities in December 2008-January 2009. UNEP, Nairobi. 
UNHRC (United Nations Human Rights Council) (2009) Human Rights in Palestine and Other Occupied Arab Territories: Report of the United Nations Fact-Finding Mission on the Gaza Conflict (the 'Goldstone Report'). A/HRC/I2/48. UNHRC, New York, NY.

UNHRL (United Nations Humanitarian Response in Lebanon) (2006) Lebanon Crisis 2006. Interim report I2 July-30 August 2006. UNHRL, Beirut.

UNMACC (United Nations Mine Action Coordination Centre) (2007) South Lebanon Cluster Bomb Info Sheet. UNMACC, Beirut.

USAID (United States Agency for International Development) (2006) Lebanon Humanitarian Emergency Situation Report. 30. 29 August. USAID, Beirut.

World Bank (2007) Lebanon: Economic and Social Impact Assessment: From Recovery to Sustainable Growth. Social and Economic Development Group, Middle East and North Africa Region, World Bank Group, Washington, DC.

Zeitoun, M. (2005) 'Conflict and water in Palestine: the consequences of armed conflict on drinkingwater systems in Jenin, West Bank'. In I. Khatib et al. (eds.) Water Values and Rights. Palestine Academy Press, Ramallah. pp.I50-I80.

Zeitoun, M. and J. Warner (2006) 'Hydro-hegemony: a framework for analysis of transboundary water conflicts'. Water Policy. 8(5). pp. 435-460.

Zeitoun, M., K. Eid-Sabbagh, M. Dajani, and M. Talhami (2012) Hydro-political Baseline of the Upper Jordan River. Association of the Friends of Ibrahim Abd el Al, Beirut.

Zeitoun, M., K. Eid-Sabbagh, M. Talhami, and M. Dajani (2013) 'Hydro-hegemony in the Upper Jordan waterscape: control and use of the flows'. Water Alternatives. 6(I). pp. 86-Io6.

Zeitoun, M., M. Talhami, and K. Eid-Sabbagh (2013) 'The influence of narratives on negotiations over and resolution of the Upper Jordan River conflict'. International Negotiation. I8(2). pp. $293-322$. 